\title{
大腿骨頸部外側骨折の観血的療法について
}

\author{
国立嬉野病院 整形外科 \\ 松 坂 誠 応・高須賀 良一 \\ 白石 公 佑・川 村 勝 彦 \\ 前田謙而・
}

\section{Surgical Treatment of Trochanteric Fractures of the Hip}

\author{
By
}

\author{
N. Matsusaka, R. Takasuga, K. Shiraishi, \\ K. Kawamura and K. Maeda \\ Department of Orthopaedic Surgery Ureshino National Hospital, Saga
}

\begin{abstract}
We reviewed 115 trochanteric fractures treated surgically from January 1972 to $\mathrm{Fe}$ bruary 1978. Sixty-eight of 115 fractures were operated by the nail-plate method. In these two groups, we compared operating time, volume of bleeding and start of weightbearing. Consequently we found that Ender's method was superior to the nailplate method. In his method to get the solid and stable fixation, it is necessary to insert the pins into the proximal fragment to more than two-thirds of its length, but not to concentrate them in the lateral part of the femoral head.
\end{abstract}

はじめに

大腿骨頸部外側骨折は特に骨癒合が悪いというもの ではないが，高令者に多発するため，何らかの合併疾 患を有し，また，治療上解剖学的整復の困難さなど多 くの問題を含んでいる. そのため，乙の骨折に対し早 期離床, 早期歩行を目的として種々の治療法が報告さ れてきた. 1969 年, Ender によって flexible condylocephalic nailing が発表されて以来, 超早期離 床・歩行が可能となり， 内外で Ender 法が従来の nail-plate 法より優れているという報告がなされて いる.

今回, われわれは nail-plate 法と Ender 法につ いて比較検討したので, Ender 法の問題点を含めて 報告する。

\section{対象および方法}

1972 年 1 月より 1978 年 2 月まで当院にて手術した 症例は, 113 症例 115 関節（男 38 例，女 75 例）であ る. 平均年令は 75 才 (30 94才) で, 70 才以上の高 令者が $80 \%$ 占めていた，骨折様式の分類は Evans
の分類に従った．安定型 55 関節 (47.8\%)，不安定型 60 関節（52.2\%）であった．骨折固定材料として McLaughlin 釘 (48 関節), Jewett 釘 (20 関節), Ender 釘（45 関節）を用い，全例，全麻下に行なっ た. 各治療法の手術時間, 出血量, 荷重開始時期, 術

表 1 症 例

\begin{tabular}{|c|c|}
\hline \multicolumn{2}{|l|}{ Material } \\
\hline \multicolumn{2}{|c|}{ surgical treatment ; 113 cases (115 hips) } \\
\hline male & ; 38 cases \\
\hline female & ; 75 cases \\
\hline age & ; 74.7 year-old $(30-94)$ \\
\hline follow-up & ; 4 mon. $\sim 6$ years \\
\hline classification of fra & ctures (Evans) \\
\hline stable fracture & ; 55 hips \\
\hline unstable fracture & ; 60 hips \\
\hline Ender pin & ; 45 \\
\hline stable fr. & ; 24 \\
\hline unstable fr. & ; 21 \\
\hline Jewett nail & ; 20 \\
\hline stable fr. & ; 10 \\
\hline unstable fr. & ; 10 \\
\hline McLaughlin nail & ; 48 \\
\hline stable fr. & ; 21 \\
\hline unstable fr. & ; 27 \\
\hline others & ; 2 \\
\hline
\end{tabular}




\begin{tabular}{|clcccc|}
\hline \multicolumn{1}{c}{ 表 2 手 } & 術 & 経 & 過 & \\
\hline Results: & & bleeding & ope.'s time & weight-bearing \\
Ender pin & stable fracture & 43.9 & 24.7 & 17.5 \\
& unstable fracture & 74.3 & 33.4 & 13.9 \\
Jewet uail & stable fracture & 204.0 & 50.5 & 45.4 \\
& unstable fracture & 305.5 & 67.3 & 64.0 \\
McLaughlin nail & stable fracture & 86.9 & 54.0 & 87.8 \\
& unsable fracture & 249.2 (gr.) & 71.0 (min.) & 100.0 (day) \\
\hline
\end{tabular}

表 3 合伝症

\begin{tabular}{|c|c|c|}
\hline Complication (Post-Ope.) & & \\
\hline \multicolumn{3}{|l|}{ Ender pin } \\
\hline varus deformity & ; & 4 cases $(9 \%)$ \\
\hline gonalgia due to descent of the pins & ; & 3 cases $(7 \%)$ \\
\hline technical failure & ; & 2 cases \\
\hline \multicolumn{3}{|l|}{ Jewett nail } \\
\hline penetration & ; & 3 cases $(15 \%)$ \\
\hline infection & ; & 1 case $(5 \%)$ \\
\hline delayed union & ; & 3 ceses $(15 \%)$ \\
\hline \multicolumn{3}{|l|}{ McLaughlin nail } \\
\hline penetration & ; & 1 case $(2 \%)$ \\
\hline bend or breakage of the nail & ; & 11 cases $(24 \%)$ \\
\hline delayed union & ; & 11 cases $(24 \%)$ \\
\hline
\end{tabular}

表 4 遠隔成績

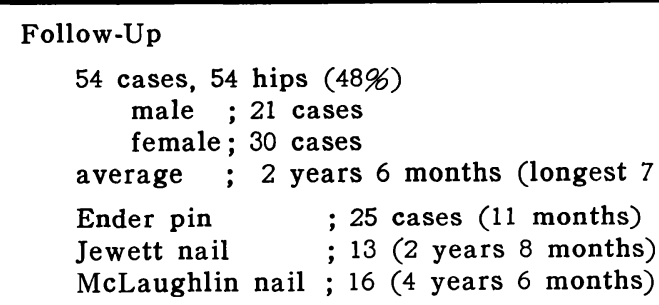

$\begin{array}{lccc}\text { sitting straight } & \text { Ender pin } & \text { Jewett nail } & \text { McLaughlin } \\ \begin{array}{l}\text { possible } \\ \text { difficult }\end{array} & 16(64 \%) & 8(62 \%) & 11(69 \%) \\ \begin{array}{l}\text { impossible } \\ \text { hip joint }\end{array} & 5(20 \%) & 2(15 \%) & 0 \\ \begin{array}{l}\text { int. rotation } \\ \text { ext. rotation }\end{array} & 4(16 \%) & 3(23 \%) & 5(31 \%) \\ \begin{array}{l}13^{\circ}\left(35^{\circ}\right) \\ 52^{\circ}\left(44^{\circ}\right)\end{array} & 26^{\circ}\left(29^{\circ}\right) & 25^{\circ}\left(31^{\circ}\right) \\ \text { union } & & 37^{\circ}\left(41^{\circ}\right) & \left(35^{\circ}\left(40^{\circ}\right)\right. \\ \text { non-union } & 0 & 0 & 0\end{array}$

前・術後合併症, 骨㿉合について調査した（表 1 ).

直接検診: 検診を受けたすのは 54 症例 54 関節で follow-up 期間は平均 2 年 6 力月で, その内訳は表 4 に示す. これらによって股関節可動域, 膝の問題, ADL について調查した.

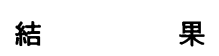

6 例を除き，全例に何らかの内科的合併疾患があっ たが, 術中・術直後の死亡例はなかった. 手術時間, 出血量, 荷重開始時期について, nail-plate 法之 
Ender 法を比較すると表 2 のどとく, Ender 法が手 術時間, 出血量とも少なく, 荷重開始時期が早い。術 後合併症について, nail-plate 法では全例が不安定 型に，Ender 法は 1 例を除き全例 が不安定型にみら れた。その内容は表 3 飞示す，骨癋合の点加ら，Jewett 釘では, 遷延治癒 3 例 (15\%), 内反変形治癒 1 例 (5\%), McLaughlin 釘では遷延治癒 9 例 (20 $\%)$, 内反変形治癒 11 例 $(24 \%)$ であった. 一方, Ender 釘では, 初期 2 例の失敗例があったが，内反 変形 4 例（9\%)，釘の皮下哭出による膝疼痛 3 例 ( 7 \%) が認められたが，遷延治瘉，偽関節は 1 例むなか った.

直接検彰：股関節の術後可動域では回旋運動が問題 となる. nail-plate 法では， 健側と比べ，内外旋と 屯，僅かに減少している．Ender 法では，内旋は平 均 $13^{\circ}$ で, 健側に比べ $23^{\circ}$ 減少し, 外旋は平均 $52^{\circ}$ で，健側に比し $8^{\circ}$ 增大している. 膝関節可動域につ いては，正坐が可能から゙うかで調べ，正坐可能な者は Ender 法 64\%, Jewett 法 62\%, McLaughlin 法 69\%之差はなかった（表 4).

$$
\text { 考察 }
$$

老人の骨脆弱性，内側骨皮質の弱さ，不安定型など から， nail-plate 法では早期荷重は内反変形，nail 折損，nail による骨頭穿通を起す危険性があり，骨 癋合を待って荷重させる必要がある（図 1). Ender 法では nail-plate 法に比べ荷重時の屈曲モーメント が小さく，早期荷重でも，矢野らは荷重による pin の変形は求こり得ないと述べわれわれの症例であ pin の変形はなかった．手術時間，出血量が Ender 法の場合少なく早期荷重が可能であり，Ender 法は 高令者飞多発する大腿骨頸部外側骨折の治療飞優れて いる. しかし，Ender 法にあ種々の問題点があるが， Ender 法の合併症を中心に考察を加えたい，

1. 内反変形 ( 4 例)：図 2,3

Kemph, I. らは, 強固で安定した固定を得るには, pin の先端を近位骨片の $2 / 3$ 以上刺入する必要がある 之述べている。 乙妃ら 4 例（全て不安定型）中 3 例は pin 先端が $2 / 3$ まで達せず，他の 1 例は $2 / 3$ 以上刺入 されていたが，pin が全て骨頭の外側に集中してい た. 内反変形が起らなかった症例では全例 $2 / 3$ 以上刺 入され，また骨頭に打ける pinの位置は，内側，中 間部，外側之様々だが，外側のみに集中しているもの

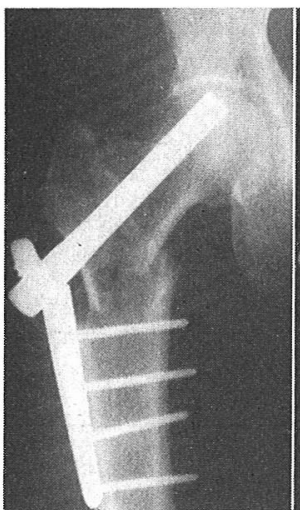

術直後

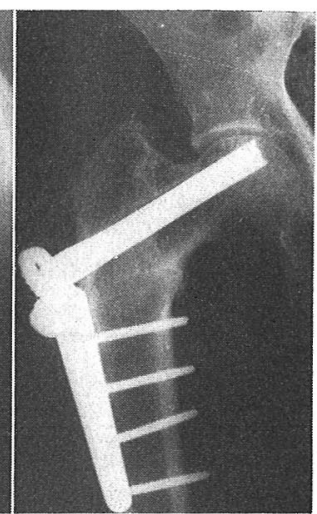

術後12力月
図 1-a McLaughlin 釬の邖区変形

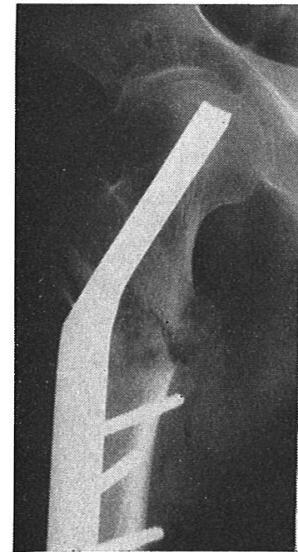

術直後

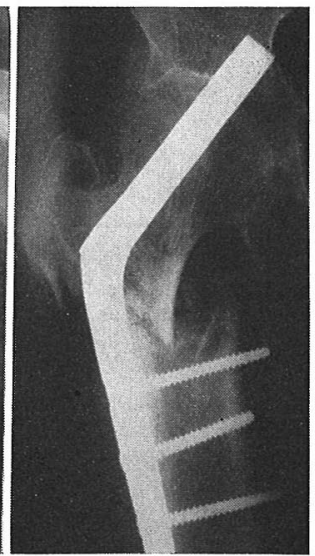

術後 3 週
図 1-b Jewett 釘による骨頭穿通

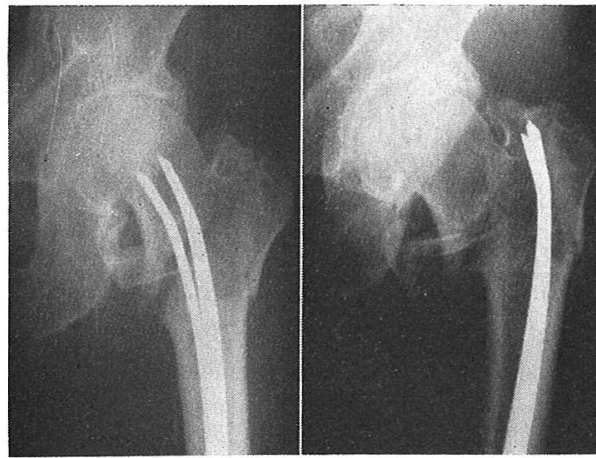

術後 3 週

術直後
図 2 Ende 釷の庆反変形 術後10日で荷重開始 


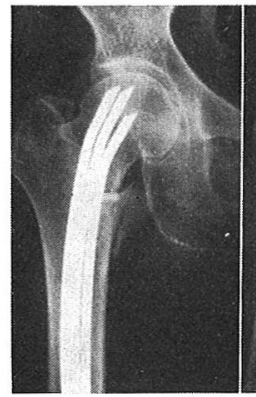

術直後

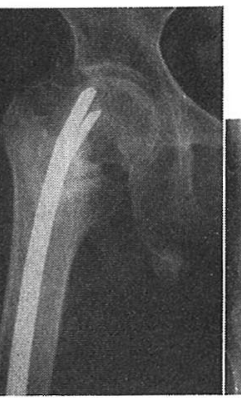

術後 3 力月

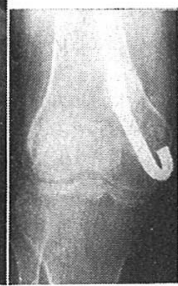

術後 3 力月
図3 内反変形と pin の皮下突出

はなかった．従って，内反变形を避けるには（特に不 安定型では), 近位骨片の $2 / 3$ 以上 pin を刺入し, 外 側のみに集中させないととが必要であると考える.

\section{2. 滕の問題}

われわれの症例では，膝内側に強い疼痛を訴えるも のが 3 例（全て不安定型）あり，いずれも pin の皮 下への哭出によるものだった．乙のような症状の原因 飞膝関節近くからの pin 刺入があるが，ての3 例は 全て大腿骨内上顆の骨膜下に走る小血管群よりやや中 枢側で刺入している． 3 例中 2 例は内反変形を起して おり (図 3 ), 内反変形によって pin が骨頭・頸部を cut-out せず distal へ押し出されたあのと考える. 他の 1 例は骨癒合完成後に起った.
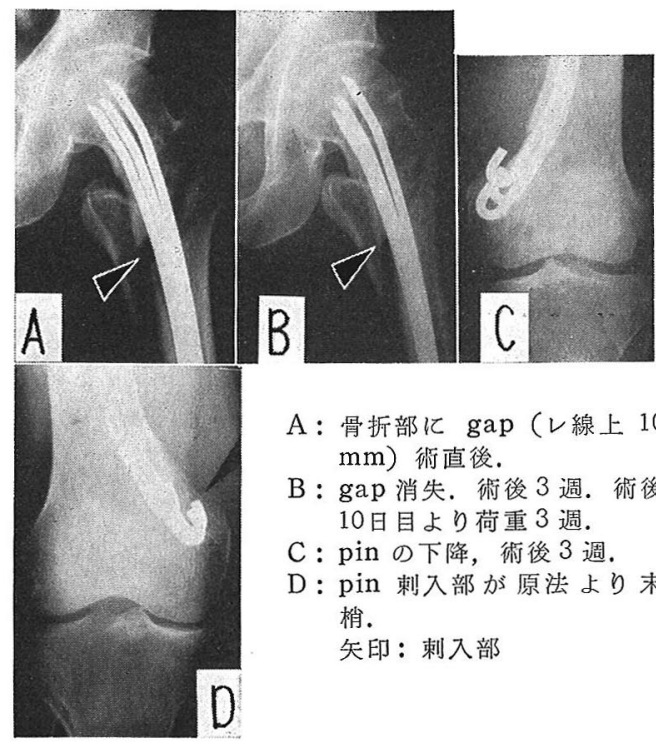

A：骨折部に gap (レ線上 10 $\mathrm{mm})$ 術直後.

B : gap 消失. 術後 3 週. 術後 10日目より荷重 3 週.

C : pin の下降, 術後 3 週.

D：pin 剌入部が原法より末 梢。

矢印：刺入部
運動性について，正坐可能な症例は 16 例 (64\%) であった．正坐困難・不能例を検討すると，不能例 （屈曲 $100^{\circ} \sim 110^{\circ}$ ） 4 例中 3 例は pin の皮下突出で強 い疼痛を有するもので, 他の 1 例は $\mathrm{OA}$ 変化が強いも のであった，後者は Ender 法の影響とは考えにく い, 困難例 (屈曲 $140^{\circ} \sim 160^{\circ}$ ) 5 例中 2 例は pin 刺 入部が原法より末梢にあり，1例は pin 刺入時骨折 部内側にレ線上 $10 \mathrm{~mm}$ の gap が生じ荷重開始後, 近位骨片が下方へずれ gap を消失させ，との時 pin あ近位骨片之同時にdistal へ下降したあのである （図 4).乙れらが可動域制限の原因と考える. 残りの 2 例は pin 刺入部む適切で, pin の下降むない, 唯, 術後 5 力月と, 術後経過が比較的短いため長期の follow-up でさらに可動域は增加するだろう，顆部髄 腔内に pin が落ち込んだ例では膝の問題は何ら生じ ていない.

3. 股関節可動域 (回旋について): 表 4

nail-plate 法では内外旋とも軽度制限があったが， Ender 法では内旋制限と外旋增加が起り，矢野らの 報告之同様である. Ender 法では，骨頭内で pin が diverge することで骨折部での 回旋を防止し，同様 な作用が膝刺入部の pin の部分にも存在する．われ われの症例では，骨頭内で pin が diverge してい る例は少なく, 膝刺入部の pin は $1 \sim 2$ 本が多くの 例で顆部䯣腔へ落ちている，安静時，下肢は重力によ って外旋するが，乙の際，pin の diverge 不足之 pin の顆部䯣腔内脱落があると, 遠位骨片が外旋し, 内旋制限，外旋增加が起ったと考元る.しかし，乙の 内旋制限により ADL 上特に困ることはなかった.

$$
\text { ま と め }
$$

1. Ender 法は nail-plate 法に比べ手術侵襲が 少なく早期荷重が可能である.

2. Ender 法の内反変形防止には，特に不安定型 において pin 先端を近位骨折の $2 / 3$ 以上刺入し, pin が外側のみに集中しないようにする必要がある.

3. Ender 法での膝の問題防止には pin の刺入を 適切にし，骨接部に大きな gap を作らぬとと。

4. Ender 法では股関節内旋制限が起ったが，特 に ADL 上困ったととはなかった。

文献

1) Evans, E. M.: J. Bone and Joint Surg., 
31-B, 190-203, 1949.

2) Ender, J.: Acta Chir. Austriaca, I, 1, 40, 1970.

3) Kuderna, H. : J. Bone and Joint Surg., 58-A, 604-11, 1976.

4) Kempf, I.: Rev. Chir. Orthop., 62, 595$612,1975$.

5) Kaufer, H.: J. Bone and Joint Surg., 56A, A, 899-906, 1974.

6) May, J. M. B., J. Bone and Joint Surg., 50-B, 318-323, 1968.

7) 敷田卓治 5: Hip Joint, 3, 205-210, 1977.

8）矢野悟 5 : 臨整外 $11,925-932,1976$.

$$
\text { 追 加 長崎労災病院 三原 和夫 }
$$

本院における転子部骨折の過去の使用金属釘につ いて年度別に集計した結果, McLaughlon 釘の直角 部の弱点から Jewett Nail に代っていき, Jewett Nail の侵襲の強さ Migration 等の Trouble から Ender 釘の使用になった変遷を述べた. 次に不安定 type に対しては Ender 釘の使用になった変遷を述 ベた.

次に不安定 type に対しては Ender 釘の使用時外 反骨切り術を追加する必要のある例をスライドで示し
た.
追 加 西尾病院 西尾 昭彦 荷重開始時期は本骨折の治療上, 大変重要な部分を 占めるが, 私自身は Ender 釘の経験はないので貴殿 の成績荷重時期の早さに瞠目している. しかし荷重開 始時期については骨折型, porosis の有無程度, 体 格, 体重, nail の位置, 方向等の諸条件が重きを占 めるので, 示された内固定材別の数值（日数）の公表 に当っては, 細かい内容の分析や注釈が必要と思われ る. 入院期間については, その上, ふつうの場合, 社 会的条件が加わるのでさらに然りである.

回答国立嬉野病院 松坂 誠応

(1) 骨折のタイプ, osteoporosis の程度等で weight-bearing の時期も異なるが今回 は便宜上, stable, unstable に分け, 比較した.

(2) 入院期間について 老人の場合, 色んな social な問題をむっているので短いからといってそれ が直接，治療成績の評価につながらないと考える. 